\title{
Laser microdissection method for neurodegenerative diseases
}

\author{
Yamaoka $\mathrm{H}^{1}$, Shimizu $\mathrm{T}^{1,2}$, Nagata $\mathrm{K}^{1}$, Tsuji $\mathrm{S}^{3}$, Morikawa $\mathrm{K}^{1}$ and Hachiya $\mathrm{N}^{\mathbf{1}^{*}}$ \\ ${ }^{1}$ Tokyo Metropolitan Industrial Technology Research Institute, 2-4-10 Aomi, Koto-ku, Tokyo 135-0064, Japan \\ ${ }^{2}$ Laboratory of Biochemistry, School of Veterinary Medicine, Azabu University, Japan \\ ${ }^{3}$ Joyful Life, Inc., 4-5 Kojimachi, Chiyoda-ku, Tokyo 102-0083, Japan
}

\begin{abstract}
Neurodegenerative disorders such as Alzheimer's disease and Parkinson's disease raise prevalence with age. The structure of the causative protein is impaired in many neurodegenerative diseases. Therefore, abnormal accumulation of proteins is observed within and outside the cell. Many of these diseases are sporadic and idiopathic with an uncertain cause, and the clues to elucidate pathophysiology are aggregates of these disease-derived proteins. However, there are no examples in which all the elements have been clarified. The study of aggregated proteins is important for correct diagnosis and selecting suitable therapies or the development of therapies and prevention. The laser microdissection (LMD) technique that can cut the submicron order region has been used for neurodegenerative disease studies in recent years. The LMD approach is also useful for isolating only particular cells from the central nervous system from the tissue. This paper provides examples of LMD study in neurodegenerative disease research and discusses their efficacy.
\end{abstract}

\section{Introduction}

It is not well understood how neurodegenerative diseases occur in a specific person and when they start, but since they tend to develop in the elderly, aging itself is considered a risk. Thus, in many countries where life expectancy is growing, the number of patients continues to increase, but unfortunately there is no preventive or curative treatment.

Most neurodegenerative diseases are protein aggregation diseases such as Alzheimer's disease and Parkinson's disease characterized by the accumulation of intracellular and extracellular deposits made up of highly aggregated pathogenic proteins.

Knowing when, where and how these intracellular aggregates are formed is perhaps the most relevant knowledge for pathophysiology clarity. However, the answer has not yet been issued. One reason is that the tissue in the central nervous system contains various types of cells in a complicated way, and it is challenging to separate only particular cells, such as neurons or glial cells. Another reason is that even though a single cell could be isolated, it is tough to highly purify the protein aggregates only from the cell using the conventional biochemical analysis process. Therefore, experimental results are unreliable due to contaminants.

Laser Microdissection (LMD), which has grown in the number of users in recent years, is an efficient way to solve these problems. This is because LMD is a device that can eliminate accidental contamination as much as possible. After all, the target will be cut when visually viewing the target under a microscope. The first inventor of the LMD process was Sergei Stepanovich Chashotin (1883-1973) and commonly used as a microsurgery instrument in the early 1960s. LMD currently has two distinct types of lasers, primarily infrared (IF) and ultraviolet (UV). Over the decades, it has been updated and improved from ultraviolet (UV) laser beams to high-energy nitrogen, infrared and carbon dioxide lasers. LMD allows the precise separation of uniform cell populations or single cells from heterogeneous populations and also allows the separation of live cells in culture dishes [1]. Thus, LMD is also a fast cell isolation method and is an excellent tool for the preservation of genomic molecules. Currently, LMD is commonly used in various fields of medical research, from neuroscience, cancer, scientific research to biomarker discovery and clinical diagnosis.

Neurodegenerative disorders cause degeneration and damage to individual neurons, but the remaining cells are largely unaffected [2]. LMD is especially useful for studying neurodegenerative diseases because it can separate the specific cells with selective fragility from tissues, however, there are still many disadvantages. The LMD itself and related consumables are costly, so even though it is known that high purity purification is possible and more accurate results can be achieved, classical biochemical analysis is required. Furthermore, while the performance of LMD has improved, it is still uneasy about extracting submicron-order deposits produced within cells using commercially available LMD.

Here, we will present some typical examples examined by LMD technique, focusing on the application of LMD findings for neurodegenerative diseases to pathological research.

*Correspondence to: Naomi Hachiya, Tokyo Metropolitan Industrial Technology Research Institute, 2-4-10 Aomi, Koto-ku, Tokyo 135-0064 Japan, Tel: +81-35530-2111, Fax: +81-3-5520-2627, Email: hachiya.naomi@iri-tokyo.jp

Key words: protein aggregation disease, neurodegeneration, protein misfolding, laser micro dissection system

Received: September 15, 2020; Accepted: September 25, 2020; Published: October 02,2020 


\section{Parkinson's disease}

Parkinson's disease (PD) is a polyphyletic neurodegenerative disease with progressive deterioration of motor neuron. Prevalence rises gradually with age [3] and is the second most prevalent neurodegenerative disorder [4,5]. In developing countries, it is commonly estimated to be $0.3 \%$ of the total population and approximately $1 \%$ of people over the age of 60 . PD exhibits ataxia, bradykinesia, hypokinesia, postural dysfunction, stiffness, leaning posture, tremor, and worsens bilateral vocal cord paralysis [6]. In addition to dysfunction of motor neuron, it has been shown that certain non-motor disfunctions such as olfactory dysfunction, visual disturbances, ocular motility disorders, neuropsychiatric symptoms such as depression and anxiety, and autonomic dysfunction are known as prodromal symptoms. Urological impairment, mood disorders and other neurobehavioral disturbances have also been identified $[7,8]$.

The key pathological shift is the progressive degeneration of dopaminergic neurons in the substantia nigra pars compacta of the basal ganglia, which induces neural circuit dysfunction, including the motor cortex region and the basal ganglia [9-12]. With selective neuronal failure in substantia nigra pars compacta, Lewy 's body, consisting mainly of $\alpha$-synuclein and inclusion bodies due to irregular deposits, becomes noticeable $[13,14]$. Degeneration of dopaminergic substantia nigra striatal neurons with Lewy bodies is considered a major neuropathological correlation for movement disorders in PD. In addition, similar damage appears in glutamatergic, cholinergic, GABAergic, tryptaminergic, noradrenalinergic and adrenergic neurons [15].

PD pathology involves ion channel activity, activity associated Ca2+ homeostasis, mitochondrial dysfunction, and increased metabolic stress [16-19]. In addition, in some familial PD cases, pathogenic mutations in the familial PD genes (PARK genes) have been identified, most of which are associated with increased metabolic stress [20-22].

Neuronal Ca2+ sensor proteins (NCS) bind to various interaction partners that react to changes in intracellular $\mathrm{Ca} 2+$ and activate different signaling pathways [23-25]. Neuronal Calcium Sensor 1 (NCS-1) is involved in a number of neural functions such as synaptic transmission and plasticity, neuronal survival and promotes mitochondrial function [26-28]. The appearance of NCS-1 in the brain increases during the neonatal phase and decreases with growth. However, increased expression is observed again during various cell disorders [29]. For example, the altered expression of NCS-1 modifies its relationship to target proteins, leading to disruption of dopaminergic signaling in multiple diseases, including schizophrenia and PD [28,30-34]. Therefore, NCS-1 is especially important in the context of activityrelated $\mathrm{Ca} 2+$ stress and dopaminergic neuronal vulnerability in $\mathrm{PD}$ $[33,34]$.

Simons et al. quantified mRNA levels of $\mathrm{Ca} 2+$ stress-related genes during NCS-1 failure using wild-type and NCS-1 knock-out mice by integrating UV laser LMD and RT-qPCR approaches and they found that NADH-ubiquinone oxidoreductase chain 1 (ND1), neuron-specific enolase 2 (ENO2), mitochondrial uncoupling proteins UCP4 and UCP5, and a familial Parkinson's disease causative gene DJ-1 (PARK7) has been specifically decreased in the melanotic dopaminergic neurons of NCS-1 KO mice [35].

\section{Huntington's disease}

Huntington's disease (HD) is an autosomal dominant, progressive neurodegenerative disease that occurs in adults. HD has a specific phenotype of distinct movement disturbances, clinical symptoms, and cognitive disability. Motor neuron symptoms include chorea, dyskinesia, and dystonia. Psychiatric symptoms such as depression, anxiety, and sleep disorder appear to precede motor symptoms [36]. Cognitive deterioration presents in low concentration, difficulty in remembering newly learned information, poor language skills, disrupted speech and impaired vision. Stiffness of motor neuron and dementia predominates during the disease progresses.

HD displays neuropathological symptoms in many areas of the brain, with the most severe degeneration occurring in the caudate nucleus and putamen. The HD causative protein is huntingtin (htt) on chromosome 4. An unstable extension of the CAG (glutamineencoding trinucleotide) repeats occurring in the first exon of the Interest Transcript 15 (IT 15) gene in HD patients. The htt glutamine tail is usually elongated 8 to 36 times in the healthy person, whereas 41 times or more in the HD group. HD can be seen with htt having 38 or more repeats of glutamine, but in rare cases it has been documented that symptoms are not evident even with up to 41 repeats [37].

Some studies have shown a clear inverse association between the number of repeats and the age at onset of HD [38-40]. Neuronal damage occurs in GABAergic neurons, which up $95 \%$ of the striatum cells [41] and dysfunction of the striatal cortical pathway and loss of pyramidal cells is widespread [42]. Striatal neurons are locally lost in $\mathrm{HD}$; therefore, $\mathrm{HD}$ is also an attractive candidate for stem cell transplantation therapy. Transplantation of stem cells to the striatum has also been shown to improve motor and cognitive dysfunction in animal models $[43,44]$. In addition, mesenchymal stromal and neural stem cells (NSCs) are tested for HD stem cell therapy $[45,46]$.

Fetal tissue contains different cells, so it is important to isolate the correct source of the cells.

In order to pick up the cells correctly, Andre et al, established a new experimental method for the LMD extraction of samples from brain slices [47]. The optimum tissue section thickness for LMD is usually $4-15 \mu \mathrm{m}$ [48], but some studies have been conducted with slices up to $200 \mu \mathrm{m}$ using UV laser cutting [49]. In their experiments, they successfully cut $400 \mu \mathrm{m}$ organ-type slices using LMD, further separating the HD transplanted stem cells from the surrounding host tissues and analyzing them with RT-qPCR.

\section{Multiple system atrophy}

Multiple System Atrophy (MSA) is an adult sporadic neurodegenerative disorder. Olivopontocerebellar atrophy (OPCA), striatonigral degeneration (SND) and Shy-Drager syndrome (SDS) are all included in the MSA. MSA affects approximately $3 / 100,000$ people annually [50,51]. The average age at onset is between 50 and 75 years $[52,53]$. The incidence rises to approximately 12 per 100,000 over 70 years of age [54].

MSA causes a relatively rapid deterioration of the central nervous system with an overall survival period of 6-10 years [55,56]. 20-75\% of MSA patients include prodromal stages of non-motor symptoms, including cardiovascular autonomic dysfunction, genitourinary and sexual dysfunction, orthostatic hypotension, REM sleep behavior disorder, and respiratory disorders preceding movement disorders. as well [57]. There are two distinct clinical subtypes, the MSA-P (mainly Parkinsonism) and the MSA-C (mainly cerebellar ataxia). MSA-P refers to patients with signs of Parkinson's disease, such as postural stiffness and dysfunction, bradykinesia, and tremor. This definition includes patients that have historically been diagnosed with SND. 
MSA-C contains more prevalent cerebellar signs such as eye movement dysfunction, cerebellar dysarthria, and ataxia in the limb. MSA-C typically involves patients previously known as OPCA classical. Both phenotypes are usually observed in patients at the later stage of the disease [58-64].

MSA confirms high-density ubiquitinated $\alpha$-synuclein aggregates containing protein aggregates known as argyrophilic glial cytoplasmic inclusion bodies (GCI) in oligodendrocytes [53,65-68]. GCIs are emerging from the early stages of neuronal failure, and found to remain even though several of the cells have lost. It is also present in the nucleus of oligodendrocytes and the cytoplasm [52].

It is suspected that $\alpha$-synuclein aggregation contributes to disruption of oligodendrocytes in the process of neuronal myelination, leading to microglial activation, and subsequent release of $a$-synuclein from defective oligodendrocytes. Adjacent neurons can take extracellularly released a synuclein. This initiates the next aggregation inside the neuron cell. In addition, it is thought that toxic $a$-synuclein will spread to neurons in other synaptic brain regions in a prion-like manner [6975]. The lack of practical support for local neurons for oligodendrocytes and the effects on neurons of $\alpha$-synuclein inclusion bodies eventually contribute to axonal dysfunction, neuronal cell death and reactive astrocytes [53,76].

A genome-wide expression profiling analysis was performed by preparing RNA samples from cerebellar white matter of MSA patients and healthy individuals using LMD [77]. NF1 (neurofibromatosis 1) associated with the myelination process, PLP1 (proteolipid protein 1) involved in the development of oligodendrocytes and maintenance of axons, and ERMN (Ermin) involved in the formation of myelin and in the maintenance and stabilization of myelin sheaths, were downregulated in patients with MSA-C. Whereas GGCX (gamma-glutamyl carboxylase) gene (OMIM: 137167) was upregulated in MSA patients that are specifically functionally associated with myelination. GGCX is necessary for the activation of vitamin K-dependent proteins [78] and mutations in this gene cause "GGCX syndrome" (OMIM: 137167). Vitamin $\mathrm{K}$ has been shown to postpone fibrosis of $\alpha$-synuclein in vitro by the interaction of $\alpha$-synuclein at a particular site at the $\mathrm{N}$-terminus [79].

\section{Amyotrophic lateral sclerosis}

Amyotrophic lateral sclerosis (ALS) is a fatal motor neuron disease characterized by degenerative changes in both upper and lower motor neurons [80,81]. $10 \%$ of ALS is known as familial ALS (FALS). Almost all these cases are inherited in an autosomal dominant manner. The remaining $90-95 \%$ of cases of ALS are sporadic ALS (SALS) with no family history [82].

Superoxide dismutase1 (SOD1) is a 153 amino acid metal enzyme, one of the three superoxide dismutase presents in humans, and was the first molecule shown to be associated with ALS [83]. SOD1 binds to copper and zinc in order to form a very stable homodimer. Mutations in the SOD1 gene are associated with a $50-80 \%$ reduction in enzyme activity $[83,84]$ indicating that loss of dismutase activity results in disease. However, later studies have shown that dismutase activity is not associated with disease severity, suggesting that toxic acquisition of functional mechanisms could be working [85]. Recent metaanalyses data have shown that pathogenic variants in SOD1 account for approximately $15-30 \%$ of FALS and less than $2 \%$ of SALS cases [86]. The majority of SOD1 gene mutations are missense mutations, and the D90A variant is the most common in the world.
TAR DNA-binding protein 43 (TDP-43) is an etiological protein of ALS present in ubiquitinated inclusion bodies located in spinal cord neuron cytoplasm in patients with SALS [87-89]. The accumulation of ubiquitin-positive TDP-43 in the brain and spinal cord is considered a pathological characteristic of ALS [90-92]. TDP-43 is composed of 414 amino acids and has a signal for nuclear localization and export [93]. It is normally located in the nucleus and is involved in multiple RNA processing steps including pre-mRNA splicing, mRNA stability control, mRNA transport, translation, and non-coding RNA regulation [94-96].

Homozygous TDP-43 null mice are non-viable, suggesting that TDP-43 is central to embryonic development [97-99].

ALS is one of the diseases mostly used in the study of LMD, and its efficacy is being studied [100-103]. Recently, Krach et al. isolated motor neurons from the lumbar area of SALS patients with early respiratory failure using LMD and profiled the expression of RNA [104]. As a consequence, they found that the CK1E protein encoded by CSNK1E, a member of the CK1 family of serine-threonine protein kinases, plays a key role in various cellular processes, such as DNA replication and repair, interacted with TDP-43. Increased expression of CK1E resulted in increased TDP-43 phosphorylation and thus these findings suggest that CK1E can influence TDP-43 phosphorylation and may be a therapeutic target for ALS.

\section{Alzheimer's disease}

Alzheimer's disease (AD) accounts for up to $80 \%$ of all dementia diagnoses [105]. Postmortem brain tissue assessment is needed for a definitive diagnosis of $\mathrm{AD}$. Relatively new clinical parameters such as biomarker identification of cerebrospinal fluid (CSF) and positron emission tomography (PET) have also become useful in recent years [88]. Available drug therapy in patients at all stages of $\mathrm{AD}$ dementia is an inhibitor of cholinesterase. Memantine is also used for mild to severe $\mathrm{AD}$ dementia. These medicines have been shown to enhance the quality of life of both patients and caregivers when prescribed for the disease at the right time however, they do not slow down or reverse the progression of disease [106].

Most cases of $\mathrm{AD}$ are sporadic. Multiple factors, such as environmental exposure, genetic risk factors, mitochondrial haplotypes, age and gender, have been identified, but the cause of $\mathrm{AD}$ development remains unknown $[88,107,108]$. Approximately $1 \%$ of $\mathrm{AD}$ cases are associated with familial mutations in either the amyloid protein precursor (APP) or the presenilin 1 (PS1) and presenilin 2 (PS2) genes specifically involved in APP processing.

Cleavage of APP on the cell membrane by $a$-secretase does not form pathological amyloid- $\beta(A \beta)$ peptides. On the other hand, cleavage by $\beta$ and $\gamma$-secretase produces the disease-causing $A \beta 40$ or $A \beta 42$ peptide, which is released into the extracellular space and becomes a major component of the extracellular aggregate amyloid plaque [106,109$112]$. In several in vitro and in vivo studies using human tissues and transgenic mice, extracellular $A \beta$ accumulates prior to the formation of extracellular plaques that directly affect synaptic function and has been shown to cause severe memory loss [113-115]. It has also been documented that $A \beta$ is present in neurons, develops $\beta$-and $\gamma$-secretase cleavage in the trans-Golgi network [116], endoplasmic reticulum (ER), endosomes, lysosomes [117], mitochondrial membrane.

[118] In addition, secreted $A \beta$ peptides can be internalized by receptor-mediated and non-receptor-mediated endocytosis [119-121]. Extensive studies also support the notion that soluble $A \beta$ oligomers are the most toxic species affecting multiple early molecular pathways that lead to synaptic dysfunction in AD [120]. 
The discovery of familial AD mutations in the APP, PS1, and PS2 genes led to an amyloid cascade hypothesis that attributed the emergence of $A \beta$ to disease. In fact, overproduction of $A \beta$ peptide is observed early in patients who develop $\mathrm{AD}$ and is important for $\mathrm{AD}$ pathology [122]. However, there have been studies of cases in which cognitive dysfunction does not occur while having substantial $A \beta$ $[123,124]$ and it is difficult to understand $\mathrm{AD}$ on its own with an amyloid cascade hypothesis.

Intracellular neurofibrillary tangles (NFTs) are another essential component of $\mathrm{AD}$. Tau is a microtubule-stabilizing protein that, when hyperphosphorylated, falls out of microtubules, leading to tau destabilizing and disrupting transport mechanisms [125]. Memory impairment in $\mathrm{AD}$ is closely correlated with hippocampal synaptic defect [126-128]. As a promoter of axonal microtubule assembly, tau plays a role in sustaining neuronal projection and influencing synaptic function. Loss of tau binding to microtubules is leading to synaptic dysfunction. However, it is unclear how tau mechanically retains synaptic plasticity or how the pathogenic version of tau impairs it. The widespread presence of $A \beta$ in the brain does not seem to contribute to the development of $\mathrm{AD}$ unless the tau is present in the affected area. These findings support the idea that synergistic interactions between $\mathrm{A} \beta$ and Tau are necessary to cause neurodegeneration in $\mathrm{AD}[129,130]$.

The hippocampus and its surrounding area are critical for memory function and are severely impaired in the early stages of AD. The pathology seen in the hippocampus consists of extreme neuronal loss, severe plaque deposition, neurofibrillary tangle (NFT) formation, and neuroinflammatory reactions. The anterior hippocampal limb, one area of the hippocampus, tends to have a distinct pathological AD profile relative to the other regions of the medial temporalis region.

Early in the $\mathrm{AD}$ disease phase, deposits containing "lake-like" diffusive $A \beta$ occur in the anterior hippocampal limb, with no aggregate morphology seen when forming with amyloid fibrils [131,132]. Components of this particular diffuse $A \beta$ deposit were studied in conjunction with LMD and mass spectrometry in both sporadic $A D$, inherited and familial AD, and Familial British Dementia (FBD) and Familial Danish Dementia (FDD) brain amyloidosis and found that the deposit contain three forms of amyloid peptides $A \beta, A B r i$, and $\mathrm{ADan}$. ABri and Adan are molecules formed by the cleaving of a type II transmembrane protein called an endogenous $2 \mathrm{~B}$ membrane protein (BRI 2). ABri and ADan cause deposits of amyloid in the blood vessels and brain. Since BRI 2 interacts with APP, the interaction between A $\beta$ and $\mathrm{ABri}$ or ADan may also be relevant to influence the rate of amyloid production or this aggregation [133-135].

Endosomal dysfunction is one of the early pathologies observed in the brain of $\mathrm{AD}$ [136]. The endosomal pathway performs many of the main functions of the neurons, including the internalization of nutrients and growth factors, the recycling of receptors and the signaling of appropriate intracellular pathways. A group of small ras-related GTPase (rab) proteins control vesicular transport to early late endosomes and other organelles along the endosome-lysosomal pathway [137]. Early endosome effector rab5 and late endosome component rab7 regulate nervous growth factor (NGF) signaling $[138,139]$. Ginsberg et al. collected a population of neurons only from deceased subjects using LMD and analyzed endosomal markers selected by a customized microarray analysis. As a result, there has been a significant upregulation of the early endosome effector genes, including the late endosome genes rab4 and rab5 [140].

In another case of the use of LMD for the study of $\mathrm{AD}$, the expression profile of hippocampal CA1 pyramidal neurons in aged Ts65Dn mice, a mice model of Down's Syndrome (DS) and Alzheimer's Disease (AD), was examined. Alldred et al isolated CA1 pyramidal neurons only by use of LMD and found that there was a down-regulation of the neurotrophin-associated receptor [141]. Neurotrophin receptors, especially BDNF and TrkB, are potent regulators of synaptic plasticity, learning, and memory [142].

\section{Frontotemporal lobar degeneration}

Frontotemporal lobar degeneration (FTLD) is a progressive neuropathy with severe behavioral, personal and verbal symptoms. It accounts for around 20\% of dementia diseases [143]. The main FTLD syndromes are frontotemporal dementia (bvFTD) with prominent personality, behavioral abnormalities, progressive non-fluent aphasia (PNFA) and semantic dementia (SD) in which the meaning of terms and products is not understood. Even if the pathological form is different, the clinical picture appears according to the topography of the lesion. Pathologically, the majority of FTLD examples aggregate particular proteins in nerve or glial cells to form inclusion bodies. Tau, TDP-43, and fused in sarcoma (FUS) have been described as major constituent proteins, comprising three major pathological groups: FTLD-tau, FTLD-TDP, and FTLD-FUS.

The histopathological characteristic of FTLD-U is ubiquitinpositive, tau, and $\alpha$-synuclein-negative intraneuronal inclusions primarily in the dentate gyrus and frontotemporal cortex of the hippocampus [144]. LMD was used to isolate the ubiquitinated inclusion of hippocampal dentate gyrus in patients with FTLD-U and the components were detected by LC-MS/MS. 73 candidate proteins with FTLD-U-specific expression changes were detected, of which 54 were found to be selectively increased in expression and 19 were found to be decreased in FTLD-U [145].

Pick's disease is a disease included in FTLD and is characterized as a constituent by Pick 's body containing phosphorylate tau. Eight of a total of 16 alternative splicing exons have six central nervous system (CNS) isoforms and six additional peripheral nervous system (PNS) isoforms [125]. Alternative splicing mainly affects the N-terminal projection region and the microtubule binding domains (MBDs), producing 4-repeat (4R) and 3-repeat (3R) tau. These two isoforms are preserved in a balanced ratio $(1: 1)$ in the adult brain and disruption of the $3 \mathrm{R}$ to $4 \mathrm{R}$ tau expression ratio induces $\mathrm{AD}$ and other tauopathy [146]. The most studied function of Tau is to promote the construction and stability of microtubules, supported primarily by studies using cell-free in vitro systems, and it has been found that $4 \mathrm{R}$ tau has more robust microtubule support activity than $3 \mathrm{R}$ tau [147]. Using LMD method, Ohkubo et al. was isolated by approximately 500 of Pick bodies and analyzed by a mass spectrometer. Consequently, they found that phosphorylate tau (69 kDa, tau 69) isoforms were accumulated in Pick bodies [148].

\section{Conclusions}

Protein aggregation disorders are often caused by aging and the number of patients is expected to continue to increase as life expectancy rises. However, many mechanisms behind these diseases have not yet been explained. In addition, unfortunately, there are currently no known preventive or curative approaches.

One of the key reasons for this is that the components of protein aggregates and disease-specific deposits have not been clarified.

As we have seen in the study of neurodegenerative diseases, it has become possible to isolate only particular cells from a complex mixture 
of tissues with LMD and to examine the components of nucleic acids and proteins. LMD is now used to address these issues in the field of neurodegenerative diseases. High-precision target separation using LMD approach is expected to accurately identify disease-derived deposit components when combined with high-sensitivity mass spectrometry. It would be fantastic if this could soon elucidate the real pathophysiology of protein aggregation and improve treatment and preventive methods.

The current pathological classification of neurodegenerative diseases associated with protein aggregation deposits is based on proteins with irregular accumulation. In order to make an appropriate diagnosis based on clinical evidence, it is important to explain the pathophysiology of neurodegenerative diseases. Highdefinition extraction of the research targets by the LMD device and the establishment of a highly accurate sample-based analysis method would become more important.

\section{Declaration of competing interest}

The authors declare no competing financial interests.

\section{Acknowledgements}

This work was supported by JSPS Grant Number JP19K2252 (N.H.).

\section{References}

1. Satori CP, Kostal V, Arriaga EA (2012) Review on recent advances in the analysis of isolated organelles. Anal Chim Acta 753: 8-18. [Crossref]

2. Standaert DG (2005) Applications of laser capture microdissection in the study of neurodegenerative disease. Arch Neurol 62: 203-205.

3. Song LK, Ma KL, Yuan YH, Mu Z, Song XY (2015) Targeted overexpression of alphaSynuclein by rAAV2/1 vectors induces progressive nigrostriatal degeneration and increases vulnerability to MPTP in mouse. PLoS One 10: e0131281.

4. Schulz JB, Hausmann L, Hardy J (2016) 199 years of Parkinson disease - what have we learned and what is the path to the future? J Neurochem 1: 3-7.

5. Obeso JA, Stamelou M, Goetz CG, Poewe W, Lang AE, et al. (2017) Past, present, and future of Parkinson's disease: A special essay on the 200th Anniversary of the Shaking Palsy. Mov Disord 32: 1264-1310.

6. Teive HA, Bertucci DCF, Munhoz RP (2016) Unusual motor and non-motor symptoms and signs in the early stage of Parkinson's disease. Arq Neuropsiquiatr 74: 781-784.

7. Wu Y, Le W, Jankovic J (2011) Preclinical biomarkers of Parkinson disease. Arch Neurol 68: 22-30.

8. Mahlknecht P, Seppi K, Poewe W (2015) The concept of prodromal Parkinson's disease. J Parkinsons Dis 5: 681-697.

9. Damier P, Hirsch EC, Agid Y, Graybiel AM (1999) The substantia nigra of the human brain. II. Patterns of loss of dopamine-containing neurons in Parkinson's disease. Brain 122: $1437-1448$

10. Surmeier DJ, Obeso JA, Halliday GM (2017) Parkinson's disease is not simply a prion disorder. J Neurosci 37: 9799-9807.

11. Giguere N, Burke Nanni S, Trudeau LE (2018) On cell loss and selective vulnerability of neuronal populations in Parkinson's disease. Front Neurol 9: 455.

12. Mazzoni P, Shabbott B, Cortes JC (2012) Motor control abnormalities in Parkinson's disease. Cold Spring Harb Perspect Med 2: a009282.

13. Miki Y, Tanji K, Mori F, Kakita A, Takahashi H (2017) PLA2G6 accumulates in lewy bodies in PARK14 and idiopathic Parkinson's disease. Neurosci Lett 645: 40-45.

14. Braak H, Ghebremedhin E, Rub U, Bratzke H, Del Tredici K (2004) Stages in the development of Parkinson's disease-related pathology. Cell Tissue Res 318: 121-134.

15. Braak H, Braak E (2000) Pathoanatomy of Parkinson's disease. J Neurol 2: 3-10.

16. Duda J, Fauler M, Grundemann J, Liss B (2018) Cell-Specific RNA quantification in human SN DA neurons from heterogeneous post-mortem midbrain samples by UVLaser microdissection and RT-qPCR. Methods Mol Biol 1723: 335-360.
17. Michel PP, Hirsch EC, Hunot S (2016) Understanding dopaminergic cell death pathways in Parkinson Disease. Neuron 90: 675-691.

18. Surmeier DJ, Halliday GM, Simuni T (2017) Calcium, mitochondrial dysfunction and slowing the progression of Parkinson's disease. Exp Neurol 298: 202-209.

19. Cherubini M, Wade-Martins R (2018) Convergent pathways in Parkinson's disease Cell Tissue Res 373: 79-90.

20. van der Brug MP, Singleton A, Gasser T, Lewis PA (2015) Parkinson's disease: From human genetics to clinical trials. Sci Transl Med 7: 205. [Crossref]

21. Deng H, Wang P, Jankovic J (2018) The genetics of Parkinson disease. Ageing Res Rev 42: 72-85.

22. Blauwendraat C, Heilbron K, Vallerga CL, Bandres-Ciga S, von Coelln R, et al. (2019) Parkinson's disease age at onset genome-wide association study: Defining heritability, genetic loci, and alpha-synuclein mechanisms. Mov Disord 34: 866-875.

23. Burgoyne RD, Haynes LP (2012) Understanding the physiological roles of the neuronal calcium sensor proteins. Mol Brain 5: 2 .

24. Choudhary D, Kragelund BB, Heidarsson PO, Cecconi C (2018) The complex conformational dynamics of neuronal calcium sensor-1: A single molecule perspective. Front Mol Neurosci 11: 468.

25. Burgoyne RD, Helassa N, McCue HV, Haynes LP (2019) Calcium sensors in neuronal function and dysfunction. Cold Spring Harb Perspect Biol 11.

26. Nakamura TY, Jeromin A, Mikoshiba K, Wakabayashi S (2011) Neuronal calcium sensor-1 promotes immature heart function and hypertrophy by enhancing $\mathrm{Ca} 2+$ signals. Circ Res 109: 512-523.

27. Angebault C, Fauconnier J, Patergnani S, Rieusset J, Danese A, et al. (2018) ERmitochondria cross-talk is regulated by the $\mathrm{Ca}(2+)$ sensor NCS1 and is impaired in Wolfram syndrome. Sci Signal 11.

28. Boeckel GR, Ehrlich BE (2018) NCS-1 is a regulator of calcium signaling in health and disease. Biochim Biophys Acta Mol Cell Res 1865: 1660-1667.

29. Pongs O, Lindemeier J, Zhu XR, Theil T, Engelkamp D, et al. (1993) Frequenin--a novel calcium-binding protein that modulates synaptic efficacy in the Drosophila nervous system. Neuron 11: 15-28.

30. Koh PO, Undie AS, Kabbani N, Levenson R, Goldman-Rakic PS (2003) Up-regulation of neuronal calcium sensor-1 (NCS-1) in the prefrontal cortex of schizophrenic and bipolar patients. Proc Natl Acad Sci U S A 100: 313-317.

31. Kabbani N, Negyessy L, Lin R, Goldman-Rakic P, Levenson R (2002) Interaction with neuronal calcium sensor NCS-1 mediates desensitization of the D2 dopamine receptor. J Neurosci 22: 8476-8486.

32. Dragicevic E, Schiemann J, Liss B (2015) Dopamine midbrain neurons in health and Parkinson's disease: emerging roles of voltage-gated calcium channels and ATPsensitive potassium channels. Neuroscience 284: 798-814.

33. Bandura J, Feng ZP (2019) Current understanding of the role of neuronal calcium sensor 1 in neurological disorders. Mol Neurobiol 56: 6080-6094.

34. Catoni C, Cali T, Brini M (2019) Calcium, dopamine and neuronal calcium sensor 1 Their contribution to parkinson's disease. Front Mol Neurosci 12: 55.

35. Simons C, Benkert J, Deuter N, Poetschke C, Pongs O (2019) NCS-1 Deficiency Affects mRNA Levels of Genes Involved in Regulation of ATP Synthesis and Mitochondrial Stress in Highly Vulnerable Substantia nigra Dopaminergic Neurons. Front Mol Neurosci 12: 252. [Crossref]

36. Spires TL, Hannan AJ (2007) Molecular mechanisms mediating pathological plasticity in Huntington's disease and Alzheimer's disease. J Neurochem 100: 874-882.

37. Rubinsztein DC, Leggo J, Coles R, Almqvist E, Biancalana V, et al. (1996) Phenotypic characterization of individuals with 30-40 CAG repeats in the Huntington disease (HD) gene reveals HD cases with 36 repeats and apparently normal elderly individuals with 36-39 repeats. Am J Hum Genet 59: 16-22.

38. Zuhlke C, Riess O, Bockel B, Lange H, Thies U (1993) Mitotic stability and meiotic variability of the (CAG)n repeat in the Huntington disease gene. Hum Mol Genet 2: 2063-2067.

39. Norremolle A, Riess O, Epplen JT, Fenger K, Hasholt L (1993) Trinucleotide repea elongation in the Huntingtin gene in Huntington disease patients from 71 Danish families. Hum Mol Genet 2: 1475-1476.

40. Tabrizi SJ, Scahill RI, Owen G, Durr A, Leavitt BR (2013) Predictors of phenotypic progression and disease onset in premanifest and early-stage Huntington's disease in the TRACK-HD study: analysis of 36-month observational data. Lancet Neurol 12: 637-649. 
41. Tepper JM, Koos T, Wilson CJ (2004) GABAergic microcircuits in the neostriatum. Trends Neurosci 27: 662-669.

42. Indersmitten T, Tran CH, Cepeda C, Levine MS (2015) Altered excitatory and inhibitory inputs to striatal medium-sized spiny neurons and cortical pyramidal neurons in the Q175 mouse model of Huntington's disease. J Neurophysiol 113: 2953-2966.

43. McLeod MC, Kobayashi NR, Sen A, Baghbaderani BA, Sadi D (2013) Transplantation of GABAergic cells derived from bioreactor-expanded human neural precursor cells restores motor and cognitive behavioral deficits in a rodent model of Huntington's disease. Cell Transplant 22: 2237-2256.

44. Yhnell E, Dunnett SB, Brooks SP (2016) A longitudinal motor characterisation of the HdhQ111 mouse model of huntington's disease. J Huntingtons Dis 5: 149-161.

45. Kerkis I, Haddad MS, Valverde CW, Glosman S (2015) Neural and mesenchymal stem cells in animal models of Huntington's disease: past experiences and future challenges. Stem Cell Res Ther 6: 232.

46. Precious SV, Zietlow R, Dunnett SB, Kelly CM, Rosser AE (2017) Is there a place for human fetal-derived stem cells for cell replacement therapy in Huntington's disease? Neurochem Int 106: 114-121.

47. Andre EM, Daviaud N, Sindji L, Cayon J, Perrot R (2018) A novel ex vivo Huntington's disease model for studying GABAergic neurons and cell grafts by laser microdissection. PLoS One 13: e193409.

48. Liu A (2010) Laser capture microdissection in the tissue biorepository. $J$ Biomol Tech 21: $120-125$.

49. Vandewoestyne M, Goossens K, Burvenich C, Van Soom A, Peelman L (2013) Laser capture microdissection: should an ultraviolet or infrared laser be used? Anal Biochem 439: 88-98.

50. Bower JH, Maraganore DM, McDonnell SK, Rocca WA (1997) Incidence of progressive supranuclear palsy and multiple system atrophy in Olmsted County, Minnesota, 1976 to 1990. Neurology 49: 1284-1288.

51. Schrag A, Ben-Shlomo Y, Quinn NP (1999) Prevalence of progressive supranuclear palsy and multiple system atrophy: a cross-sectional study. Lancet 354: 1771-1775.

52. Nishie M, Mori F, Yoshimoto M, Takahashi H, Wakabayashi K (2004) A quantitative investigation of neuronal cytoplasmic and intranuclear inclusions in the pontine and inferior olivary nuclei in multiple system atrophy. Neuropathol Appl Neurobiol 30: 546-554.

53. Stefanova N, Bucke P, Duerr S, Wenning GK (2009) Multiple system atrophy: an update. Lancet Neurol 8: 1172-1178.

54. Chrysostome V, Tison F, Yekhlef F, Sourgen C, Baldi I (2004) Epidemiology of multiple system atrophy: a prevalence and pilot risk factor study in Aquitaine, France. Neuroepidemiology 23: 201-208.

55. Gilman S, Wenning GK, Low PA, Brooks DJ, Mathias CJ (2008) Second consensus statement on the diagnosis of multiple system atrophy. Neurology 71: 670-676.

56. Jecmenica-Lukic M, Poewe W, Tolosa E, Wenning GK (2012) Premotor signs and symptoms of multiple system atrophy. Lancet Neurol 11: 361-368.

57. Xie T, Kang UJ, Kuo SH, Poulopoulos M, Greene P (2015) Comparison of clinical features in pathologically confirmed PSP and MSA patients followed at a tertiary center. NPJ Parkinsons Dis 1: 15007.

58. Mitsui J, Koguchi K, Momose T, Takahashi M, Matsukawa T (2017) Three-Year follow-up of high-dose ubiquinol supplementation in a case of familial multiple system atrophy with compound heterozygous COQ2 mutations. Cerebellum 16: 664-672.

59. Kim HJ, Jeon BS, Jellinger KA (2015) Diagnosis and differential diagnosis of MSA: boundary issues. J Neurol 262: 1801-1813. [Crossref]

60. Curry-Hyde A, Chen BJ, Ueberham U, Arendt T, Janitz M (2018) Multiple system atrophy: Many lessons from the transcriptome. Neuroscientist 24: 294-307.

61. Koga S, Aoki N, Uitti RJ, van Gerpen JA, Cheshire WP (2015) When DLB, PD, and PSP masquerade as MSA: an autopsy study of 134 patients. Neurology 85: 404-412.

62. Mestre TA, Gupta A, Lang AE (2016) MRI signs of multiple system atrophy preceding the clinical diagnosis: the case for an imaging-supported probable MSA diagnostic category. J Neurol Neurosurg Psychiatry 87: 443-444.

63. Rizzo G, Copetti M, Arcuti S, Martino D, Fontana A (2016) Accuracy of clinical diagnosis of Parkinson disease: A systematic review and meta-analysis. Neurology 86 566-576.

64. Krismer F, Jellinger KA, Scholz SW, Seppi K, Stefanova N (2014) Multiple system atrophy as emerging template for accelerated drug discovery in alpha-synucleinopathies. Parkinsonism Relat Disord 20: 793-799.
65. Bhidayasiri R, Ling H (2008) Multiple system atrophy. Neurologist 14: 224-237.

66. Papp MI, Kahn JE, Lantos PL (1989) Glial cytoplasmic inclusions in the CNS of patients with multiple system atrophy (striatonigral degeneration, olivopontocerebellar atrophy and Shy-Drager syndrome). J Neurol Sci 94: 79-100.

67. Al-Chalabi A, Durr A, Wood NW, Parkinson MH, Camuzat A (2009) Genetic variants of the alpha-synuclein gene SNCA are associated with multiple system atrophy. PLoS One 4: e7114.

68. Allen M, Carrasquillo MM, Funk C, Heavner BD, Zou F (2016) Human whole genome genotype and transcriptome data for Alzheimer's and other neurodegenerative diseases. Sci Data 3: 160089.

69. Jellinger KA (2018) Multiple system atrophy: An Oligodendroglioneural Synucleinopathy1. J Alzheimers Dis 62: 1141-1179.

70. Dehay B, Vila M, Bezard E, Brundin P, Kordower JH (2016) Alpha-synuclein propagation: New insights from animal models. Mov Disord 31: 161-168.

71. McCann H, Cartwright H, Halliday GM (2016) Neuropathology of alpha-synuclein propagation and braak hypothesis. Mov Disord 31: 152-160.

72. Woerman AL, Watts JC, Aoyagi A, Giles K, Middleton LT (2018) Alpha-Synuclein: Multiple system atrophy prions. Cold Spring Harb Perspect Med 8.

73. Goedert M, Masuda-Suzukake M, Falcon B (2017) Like prions: the propagation of aggregated tau and alpha-synuclein in neurodegeneration. Brain 140: 266-278.

74. Rohan Z, Milenkovic I, Lutz MI, Matej R, Kovacs GG (2016) Shared and distinct patterns of oligodendroglial response in alpha-synucleinopathies and tauopathies. $J$ Neuropathol Exp Neurol 75: 1100-1109.

75. Valera E, Monzio Compagnoni G, Masliah E (2016) Review: Novel treatment strategies targeting alpha-synuclein in multiple system atrophy as a model of synucleinopathy. Neuropathol Appl Neurobiol 42: 95-106.

76. Darbelli L, Choquet K, Richard S, Kleinman CL (2017) Transcriptome profiling of mouse brains with qkI-deficient oligodendrocytes reveals major alternative splicing defects including self-splicing. Sci Rep 7: 7554.

77. Piras IS, Bleul C, Schrauwen I, Talboom J, Llaci L (2020) Transcriptional profiling of multiple system atrophy cerebellar tissue highlights differences between the parkinsonian and cerebellar sub-types of the disease. Acta Neuropathol Commun 8: 76

78. Suleiman L, Negrier C, Boukerche H (2013) Protein S: A multifunctional anticoagulant vitamin K-dependent protein at the crossroads of coagulation, inflammation, angiogenesis, and cancer. Crit Rev Oncol Hematol 88: 637-654.

79. da Silva FL, Coelho Cerqueira E, de Freitas MS, Goncalves DL, Costa LT (2013) Vitamins $\mathrm{K}$ interact with N-terminus alpha-synuclein and modulate the protein fibrillization in vitro. Exploring the interaction between quinones and alpha-synuclein. Neurochem Int 62: 103-112.

80. Rowland LP, Shneider NA (2001) Amyotrophic lateral sclerosis. N Engl J Med 344 1688-1700.

81. Chow CY, Landers JE, Bergren SK, Sapp PC, Grant AE (2009) Deleterious variants of FIG4, a phosphoinositide phosphatase, in patients with ALS. Am J Hum Genet 84: 85-88.

82. Chen S, Sayana P, Zhang X, Le W (2013) Genetics of amyotrophic lateral sclerosis: an update. Mol Neurodegener 8: 28.

83. Rosen DR, Siddique T, Patterson D, Figlewicz DA, Sapp P, et al. (1993) Mutations in $\mathrm{Cu} / \mathrm{Zn}$ superoxide dismutase gene are associated with familial amyotrophic latera sclerosis. Nature 362: 59-62. [Crossref]

84. Deng HX, Hentati A, Tainer JA, Iqbal Z, Cayabyab A, et al. (1993) Amyotrophic lateral sclerosis and structural defects in $\mathrm{Cu}, \mathrm{Zn}$ superoxide dismutase. Science 261: 10471051.

85. Cleveland DW, Laing N, Hurse PV, Brown RH, Jr (1995) Toxic mutants in Charcot's sclerosis. Nature 378: 342-343.

86. Zou ZY, Zhou ZR, Che CH, Liu CY, He RL (2017) Genetic epidemiology of amyotrophic lateral sclerosis: a systematic review and meta-analysis. J Neurol Neurosurg Psychiatry 88: 540-549.

87. Leigh PN, Whitwell H, Garofalo O, Buller J, Swash M (1991) Ubiquitin-immunoreactive intraneuronal inclusions in amyotrophic lateral sclerosis. Morphology, distribution, and specificity. Brain 114: 775-788.

88. Arai T, Hasegawa M, Akiyama H, Ikeda K, Nonaka T (2006) TDP-43 is a component of ubiquitin-positive tau-negative inclusions in frontotemporal lobar degeneration and amyotrophic lateral sclerosis. Biochem Biophys Res Commun 351: 602-611. 
89. Neumann M (2009) Molecular neuropathology of TDP-43 proteinopathies. Int J Mol Sci 10: 232-246.

90. Giordana MT, Piccinini M, Grifoni S, De Marco G, Vercellino M (2010) TDP-43 redistribution is an early event in sporadic amyotrophic lateral sclerosis. Brain Pathol 20: 351-360.

91. Schipper LJ, Raaphorst J, Aronica E, Baas F, de Haan R (2016) Prevalence of brain and spinal cord inclusions, including dipeptide repeat proteins, in patients with the C9ORF72 hexanucleotide repeat expansion: a systematic neuropathological review. Neuropathol Appl Neurobiol 42: 547-560.

92. Takeuchi R, Tada M, Shiga A, Toyoshima Y, Konno T (2016) Heterogeneity of cerebral TDP-43 pathology in sporadic amyotrophic lateral sclerosis: Evidence for clinicopathologic subtypes. Acta Neuropathol Commun 4: 61.

93. Ayala YM, Zago P, D'Ambrogio A, Xu YF, Petrucelli L (2008) Structural determinants of the cellular localization and shuttling of TDP-43. J Cell Sci 121: 3778-3785.

94. Buratti E, Baralle FE (2010) The multiple roles of TDP-43 in pre-mRNA processing and gene expression regulation. RNA Biol 7: 420-429.

95. Tollervey JR, Curk T, Rogelj B, Briese M, Cereda M (2011) Characterizing the RNA targets and position-dependent splicing regulation by TDP-43. Nat Neurosci 14: 452458 .

96. Ratti A, Buratti E (2016) Physiological functions and pathobiology of TDP-43 and FUS/TLS proteins. J Neurochem 1: 95-111.

97. Kraemer BC, Schuck T, Wheeler JM, Robinson LC, Trojanowski JQ (2010) Loss of murine TDP-43 disrupts motor function and plays an essential role in embryogenesis. Acta Neuropathol 119: 409-419.

98. Sephton CF, Good SK, Atkin S, Dewey CM, Mayer P (2010) TDP-43 is a developmentally regulated protein essential for early embryonic development. $J$ Biol Chem 285: 6826-6834.

99. Wu LS, Cheng WC, Hou SC, Yan YT, Jiang ST (2010) TDP-43, a neuro-pathosignature factor, is essential for early mouse embryogenesis. Genesis 48: 56-62.

100. Cooper-Knock J, Bury JJ, Heath PR, Wyles M, Higginbottom A (2015) C9ORF72 GGGGCC expanded repeats produce splicing dysregulation which correlates with disease severity in amyotrophic lateral sclerosis. PLoS One 10: e0127376.

101. Cooper-Knock J, Green C, Altschuler G, Wei W, Bury JJ, Heath PR (2017) A datadriven approach links microglia to pathology and prognosis in amyotrophic lateral sclerosis. Acta Neuropathol Commun 5: 23.

102. Jiang YM, Yamamoto M, Kobayashi Y, Yoshihara T, Liang Y (2005) Gene expression profile of spinal motor neurons in sporadic amyotrophic lateral sclerosis. Ann Neurol 57: 236-251.

103. Rabin SJ, Kim JM, Baughn M, Libby RT, Kim YJ (2010) Sporadic ALS has compartment-specific aberrant exon splicing and altered cell-matrix adhesion biology. Hum Mol Genet 19: 313-328.

104. Krach F, Batra R, Wheeler EC, Vu AQ, Wang R (2018) Transcriptome-pathology correlation identifies interplay between TDP-43 and the expression of its kinase CK1E in sporadic ALS. Acta Neuropathol 136: 405-423.

105. Alquezar C, Salado IG, de la Encarnacion A, Perez DI, Moreno F (2016) Targeting TDP-43 phosphorylation by Casein Kinase-1delta inhibitors: a novel strategy for the treatment of frontotemporal dementia. Mol Neurodegener 11: 36 .

106. Bahia El Idrissi N, Bosch S, Ramaglia V, Aronica E, Baas F (2016) Complement activation at the motor end-plates in amyotrophic lateral sclerosis. $J$ Neuroinflammation 13: 72.

107. Amlie-Wolf A, Ryvkin P, Tong R, Dragomir I, Suh E, et al. (2015) Transcriptomic changes due to cytoplasmic TDP-43 expression reveal dysregulation of histone transcripts and nuclear chromatin. PLoS One 10: e0141836.

108. Anneser JM, Chahli C, Ince PG, Borasio GD, Shaw PJ (2004) Glial proliferation and metabotropic glutamate receptor expression in amyotrophic lateral sclerosis. $J$ Neuropathol Exp Neurol 63: 831-840. [Crossref]

109. Beers DR, Henkel JS, Zhao W, Wang J, Huang A (2011) Endogenous regulatory $\mathrm{T}$ lymphocytes ameliorate amyotrophic lateral sclerosis in mice and correlate with disease progression in patients with amyotrophic lateral sclerosis. Brain 134: 12931314.

110. Choksi DK, Roy B, Chatterjee S, Yusuff T, Bakhoum MF (2014) TDP-43 Phosphorylation by casein kinase Iepsilon promotes oligomerization and enhances toxicity in vivo. Hum Mol Genet 23: 1025-1035.
111. Russo C, Violani E, Salis S, Venezia V, Dolcini V, Damonte G (2002) Pyroglutamatemodified amyloid beta-peptides--AbetaN3(pE)--strongly affect cultured neuron and astrocyte survival. J Neurochem 82: 1480-1489.

112. Szaruga M, Veugelen S, Benurwar M, Lismont S, Sepulveda-Falla D (2015) Qualitative changes in human gamma-secretase underlie familial Alzheimer's disease. J Exp Med 212: 2003-2013.

113. Gyure KA, Durham R, Stewart WF, Smialek JE, Troncoso JC (2001) Intraneuronal abeta-amyloid precedes development of amyloid plaques in down syndrome. Arch Pathol Lab Med 125: 489-492.

114. Oddo S, Caccamo A, Shepherd JD, Murphy MP, Golde TE (2003) Triple-transgenic model of Alzheimer's disease with plaques and tangles: intracellular Abeta and synaptic dysfunction. Neuron 39: 409-421.

115. Knobloch M, Konietzko U, Krebs DC, Nitsch RM (2007) Intracellular abeta and cognitive deficits precede beta-amyloid deposition in transgenic arcAbeta mice. Neurobiol Aging 28: 1297-1306.

116. Xu H, Greengard P, Gandy S (1995) Regulated formation of golgi secretory vesicles containing Alzheimer beta-amyloid precursor protein. J Biol Chem 270: 2324323245 .

117. Kinoshita A, Fukumoto H, Shah T, Whelan CM, Irizarry MC (2003) Demonstration by FRET of BACE interaction with the amyloid precursor protein at the cell surface and in early endosomes. J Cell Sci 116: 3339-3346.

118. Mizuguchi M, Ikeda K, Kim SU (1992) Differential distribution of cellular forms of beta-amyloid precursor protein in murine glial cell cultures. Brain Res 584: 219-225.

119. Omtri RS, Davidson MW, Arumugam B, Poduslo JF, Kandimalla KK (2012) Differences in the cellular uptake and intracellular itineraries of amyloid beta proteins 40 and 42: ramifications for the Alzheimer's drug discovery. Mol Pharm 9: 18871897.

120. Cleary JP, Walsh DM, Hofmeister JJ, Shankar GM, Kuskowski MA (2005) Natural oligomers of the amyloid-beta protein specifically disrupt cognitive function. Nat Neurosci 8: 79-84.

121. Lai AY, McLaurin J (2010) Mechanisms of amyloid-Beta Peptide uptake by neurons: the role of lipid rafts and lipid raft-associated proteins. Int J Alzheimers Dis 2011: 548380 .

122. Jack CR Jr, Holtzman DM (2013) Biomarker modeling of Alzheimer's disease. Neuron 80: 1347-1358.

123. Crystal H, Dickson D, Fuld P, Masur D, Scott R (1988) Clinico-pathologic studies in dementia: nondemented subjects with pathologically confirmed Alzheimer's disease. Neurology 38: 1682-1687.

124. Iacono D, Resnick SM, O'Brien R, Zonderman AB, An Y (2014) Mild cognitive impairment and asymptomatic Alzheimer disease subjects: equivalent beta-amyloid and tau loads with divergent cognitive outcomes. J Neuropathol Exp Neurol 73: 295304.

125. Andreadis A (2005) Tau gene alternative splicing: expression patterns, regulation and modulation of function in normal brain and neurodegenerative diseases. Biochim Biophys Acta 1739: 91-103.

126. Nagy Z, Jobst KA, Esiri MM, Morris JH, King EM (1996) Hippocampal pathology reflects memory deficit and brain imaging measurements in Alzheimer's disease: clinicopathologic correlations using three sets of pathologic diagnostic criteria. Dementia 7: 76-81.

127. Hyman BT, Van Hoesen GW, Damasio AR, Barnes CL (1984) Alzheimer's disease: cell-specific pathology isolates the hippocampal formation. Science 225: 1168-1170.

128. Selkoe DJ (2002) Alzheimer's disease is a synaptic failure. Science 298: 789-791.

129. Ossenkoppele R, Schonhaut DR, Scholl M, Lockhart SN, Ayakta N (2016) Tau PET patterns mirror clinical and neuroanatomical variability in Alzheimer's disease. Brain 139: $1551-1567$

130. Wang L, Benzinger TL, Su Y, Christensen J, Friedrichsen K (2016) Evaluation of tau imaging in staging alzheimer disease and revealing interactions between betaamyloid and tauopathy. JAMA Neurol 73: 1070-1077.

131. Akiyama H, Tago H, Itagaki S, McGeer PL (1990) Occurrence of diffuse amyloid deposits in the presubicular parvopyramidal layer in Alzheimer's disease. Acta Neuropathol 79: 537-544. [Crossref]

132. Wisniewski HM, Sadowski M, Jakubowska-Sadowska K, Tarnawski M, Wegiel J (1998) Diffuse, lake-like amyloid-beta deposits in the parvopyramidal layer of the presubiculum in Alzheimer disease. J Neuropathol Exp Neurol 57: 674-683. 
133. Kim SH, Wang R, Gordon DJ, Bass J, Steiner DF (1999) Furin mediates enhanced production of fibrillogenic ABri peptides in familial British dementia. Nat Neurosci 2: $984-988$.

134. Matsuda S, Giliberto L, Matsuda Y, Davies P, McGowan E (2005) The familial dementia BRI2 gene binds the Alzheimer gene amyloid-beta precursor protein and inhibits amyloid-beta production. J Biol Chem 280: 28912-28916.

135. Matsuda S, Giliberto L, Matsuda Y, McGowan EM, D'Adamio L (2008) BRI2 inhibits amyloid beta-peptide precursor protein processing by interfering with the docking of secretases to the substrate. J Neurosci 28: 8668-8676.

136. Nixon RA, Mathews PM, Cataldo AM (2001) The neuronal endosomal-lysosoma system in Alzheimer's disease. J Alzheimers Dis 3: 97-107.

137. Ng EL, Tang BL (2008) Rab GTPases and their roles in brain neurons and glia. Brain Res Rev 58: 236-246.

138. Liu J, Lamb D, Chou MM, Liu YJ, Li G (2007) Nerve growth factor-mediated neurite outgrowth via regulation of Rab5. Mol Biol Cell 18: 1375-1384.

139. Valdez G, Philippidou P, Rosenbaum J, Akmentin W, Shao Y (2007) Trk-signaling endosomes are generated by Rac-dependent macroendocytosis. Proc Natl Acad Sci US A 104: 12270-12275.

140. Ginsberg SD, Mufson EJ, Alldred MJ, Counts SE, Wuu J (2011) Upregulation of select rab GTPases in cholinergic basal forebrain neurons in mild cognitive impairment and Alzheimer's disease. J Chem Neuroanat 42: 102-110.
141. Alldred MJ, Lee SH, Petkova E, Ginsberg SD (2015) Expression profile analysis of hippocampal CA1 pyramidal neurons in aged Ts65Dn mice, a model of Down syndrome (DS) and Alzheimer's disease (AD). Brain Struct Funct 220: 2983-2996.

142. Leal G, Afonso PM, Salazar IL, Duarte CB (2015) Regulation of hippocampal synaptic plasticity by BDNF. Brain Res 1621: 82-101

143. Kumar-Singh S, Van Broeckhoven C (2007) Frontotemporal lobar degeneration: current concepts in the light of recent advances. Brain Pathol 17: 104-114.

144. Kovari E, Gold G, Giannakopoulos P, Bouras C (2004) Cortical ubiquitin-positive inclusions in frontotemporal dementia without motor neuron disease: a quantitative immunocytochemical study. Acta Neuropathol 108: 207-212.

145. Gozal YM, Dammer EB, Duong DM, Cheng D, Gearing M (2011) Proteomic analysis of hippocampal dentate granule cells in frontotemporal lobar degeneration: application of laser capture technology. Front Neurol 2: 24.

146. D'Souza I, Schellenberg GD (2005) Regulation of tau isoform expression and dementia. Biochim Biophys Acta 1739: 104-115. [Crossref]

147. Mandelkow EM, Schweers O, Drewes G, Biernat J, Gustke N (1996) Structure, microtubule interactions, and phosphorylation of tau protein. Ann N Y Acad Sci 777: 96-106.

148. Ohkubo T, Sakasegawa Y, Toda H, Kishida H, Arima K (2006) Three-repeat Tau 69 is a major tau isoform in laser-microdissected Pick bodies. Amyloid 13: 1-5.

Copyright: $\odot 2020$ Yamaoka H. This is an open-access article distributed under the terms of the Creative Commons Attribution License, which permits unrestricted use, distribution, and reproduction in any medium, provided the original author and source are credited. 